\title{
Россия на Шпицбергене: история изучения, проблемы освоения недр и перспективы на будущее
}

А.Н. ЕВдОКИмОВ ${ }^{1}$, доктор геолого-минералогических наук, Санкт-Петербургский горный университет, Санкт-Петербург А.н. СИРОткин, доктор геолого-минералогических наук, главный геолог Шпицбергенской партии Полярной морской геологоразведочной экспедиции, г. Ломоносов

Я.В. КРЮКОВ, кандидат экономических наук, Центр ресурсной экономики ИЭОПП СО РАН, г. Новосибирск

На архипелаге Шпицберген располагаются малоизвестные российские территории с официальным статусом «собственных земель». Здесь разведано несколько месторождений каменного угля, разработкой которых занимаются государственный трест «Арктикуголь» на месторождении Баренцбург и норвежская «Стуре Ношке» вблизи Лонгиербюена. Россия в советское время выполнила весь спектр геологических исследований архипелага, уделяя основное внимание картографированию и исследованию запасов полезных ископаемых: угля, нефти, фосфоритов, полиметаллов, золота. Однако норвежская администрация архипелага всячески тормозит возможность их дальнейшего изучения и освоения, выдвигая экологические мотивы невозможности ведения геологоразведочных работ. Сохранение российского присутствия на архипелаге, по мере завершения запасов угля, представляется в реализации научных программ под эгидой образованного в 2014 г. в Баренцбурге Российского научно-исследовательского центра. Ключевые слова: Шпицберген, российское присутствие в Арктике, геологические исследования, экономика северных территорий, Норвегия, международное сотрудничество в Арктике

Исторически сложившийся интерес России к архипелагу Шпицберген обусловлен его стратегически близким к России географическим положением на северо-западе Баренцева моря. Описания походов на Грумант (древнерусское название Шпицбергена) за морским зверем сохранились в литературе и в воспоминаниях русских поморов, населяющих побережья Белого и Баренцева морей. Здесь располагаются малоизвестные российские территории с официальным статусом «собственных земель» (земли, зарегистрированные в Норвегии в качестве негосударственной собственности, но принадлежащие российским

\footnotetext{
${ }^{1}$ Евдокимов А.Н. в 1985-1987 гг. -главный геолог геологоразведочной экспедиции треста «Арктикуголь» на Шпицбергене.
} 
компаниям), работает консульство России, сохраняются следы пребывания русских поморов: остовы изб, навигационные знаки, орудия охоты и предметы быта.

\section{Немного истории}

Первоначально рыболовством и охотой на морского зверя, а затем географическими и изыскательскими исследованиями на островах архипелага занимались представители почти всех приарктических государств, что нашло отражение в разных географических названиях бухт, проливов, островов и земель. На Шпицбергене сохранились и русские названия - Земля Себина (лейтенанта), Русская бухта, мыс Ивана Старостина, хребет Ломоносова, гора Кропоткина и многие другие. После длительного периода стихийного освоения архипелага, в котором принимали участие также американцы, голландцы, шведы, англичане, итальянцы и представители многих других наций, был заключен международный договор о Шпицбергене, в результате которого хозяйственная деятельность на архипелаге стала упорядоченной. Наиболее основательно здесь закрепились норвежцы и русские, главной промышленной специализацией стала разработка угольных месторождений. Международным договором о Шпицбергене (1920 г.) определено, что Норвегия и еще 30 стран обладают равными правами на осуществление деятельности на архипелаге при условии соблюдения законодательства Норвегии.

Промышленное освоение Шпицбергена Россией началось в 1913 г., когда товарищество «Грумант» - Торговый дом А.Г. Агафелов и $\mathrm{K}^{\circ}$, организованное архангельскими и петербургскими коммерсантами с привлечением иностранного капитала, начало отгружать уголь с архипелага. Норвежские компании приступили здесь к работе в 1906 г.

Вклад России в изучение и освоение архипелага весьма значителен, и только революция 1917 г. и последующая Гражданская война помешали нашей стране претендовать на суверенитет над Шпицбергеном. Поэтому Россия не принимала участия в подписании договора о Шпицбергене в 1920 г., а присоединилась к нему лишь в 1935 г. На самом большом острове - Западный Шпицберген - разведано несколько месторождений каменного угля, разработкой которых занимаются государственный трест «Арктикуголь» (месторождения «Баренцбург», «Пирамида»,
«Грумант») и норвежская «Стуре Ношке». На Шпицбергене расположены два российских поселка (Баренцбург и Пирамида) и три норвежских (Лонгиербюен, Свеагруве и Ню-Олесунн). Основные административно-управленческие структуры (губернатор, полиция, экологическая служба и служба горного инспектора) размещены в Лонгиербюене. Их статус и сферы деятельности регламентированы международным договором 1920 г. и его неотъемлемым приложением - Горным уставом.

В соответствии с текстом договора Норвегия обеспечивает правопорядок на Шпицбергене, назначает губернатора и горного инспектора из числа норвежских граждан, обеспечивает соблюдение всех его пунктов, включая правила открытия, разведки и эксплуатации месторождений полезных ископаемых, контролирует соблюдение запрета на ведение военной и политической деятельности, требований по охране труда и защите природы, радио- и почтовую связь, соблюдение правил судоходства и авиаперелетов.

Близость к Северному полюсу Земли сделала Шпицберген стартовой площадкой для его покорителей. Сохранился памятный знак в Ню-Олесунне - самом северном из норвежских поселков, откуда стартовал экипаж экспедиции Нобиле на аэростате «Италия» и где сейчас располагается базовая станция Норвежского Полярного института.

\section{Геологическое изучение Шпицбергена в советский период}

Для проведения геологических исследований Шпицберген является уникальным объектом - более миллиарда лет истории планеты здесь лежат в буквальном смысле на поверхности. Так что геология - главная научная дисциплина на архипелаге. На Шпицбергене был представлен почти весь спектр геологических исследований, но уже с конца XIX в. основное внимание уделялось картографированию и исследованию запасов полезных ископаемых (прежде всего, нефти и угля). СССР в 1960-е гг. построил крупную геологическую исследовательскую базу вблизи Баренцбурга. Интерес к поиску ископаемого топлива на архипелаге, пережив резкий подъем в 1960-е гг., затем постепенно снижался. 
Нельзя не отметить, что значительный вклад СССР и России в изучение Шпицбергена на протяжении последних десятилетий в большой мере вызван желанием укрепить свои позиции на архипелаге. Активные исследования также были важны с точки зрения возможности контролировать деятельность Норвегии и других стран. Исследования, особенно полевые, более удобны для такого контроля, чем статичная по своей сути добыча угля. В связи с этим российские исследования на архипелаге развивались параллельно с поиском шпицбергенских месторождений нефти на международном уровне, начатом в 1960-е гг.

Решение задач по изучению геологии и поиску полезных ископаемых на Шпицбергене было поручено правительством СССР в 1962 г. Научно-исследовательскому институту геологии Арктики (НИИГА) - ВНИИОкеангеологии. В то время НИИГА был единственным институтом, который имел опыт геологосъемочных и поисковых работ на арктических архипелагах и прибрежной суше. Шпицбергенская экспедиция создана в 1962 г. по распоряжению Совмина СССР в структуре отдела горючих полезных ископаемых института.

Важным событием в истории геологических работ на архипелаге стало бурение в 1974 г. глубокой опорно-параметрической скважины «Грумантская-1» в Колсбее с помощью легендарного ледокола «Красин», специально переоснащенного для этой цели. Скважина была пробурена до глубины 3173 м [Наука.., 2009], при ее испытании получены небольшие притоки жирного метанового газа. В том же 1974 г. компанией Norsk Polar Navigation был получен небольшой приток газа на месторождении «Сарс», но надежды на обнаружение крупных залежей не оправдались.

В 1985 г. на северном берегу Ван-Майен-фьорда объединением «Архангельскгеология» была заложена скважина Вассдаленская-1. При глубине 2481 м был получен приток сухого газа с дебитом до 30 тыс. м³/сут. Ценой больших усилий фонтанирование газа было остановлено, а бурение второго ствола рядом с первым позволило повторно получить такой же приток. Одновременно буровые работы с аналогичными поисковыми, а формально параметрическими целями осуществляла норвежская компания A/S Tundra на площади Тромсёбреен на юге архипелага. В результате в тех же отложениях были получены скромные притоки газа в двух скважинах - Хакетанген-1 и Хакетанген-2.
В сентябре 1988 г. на устье скважины в районе Колсбея с глубины 238 м произошел самоизлив густой тяжелой нефти, сопровождаемый кратковременными выбросами газа. Факт появления нефти в скважине показал, что многочисленные, но небольшие нефтепроявления, давно известные в горных выработках рудника «Баренцбург», не были случайностью. По составу нефть тяжелая, парафинистая.

Особо важными для оценки нефтегазового потенциала возможных скоплений углеводородного сырья на архипелаге представляются данные, полученные трестом «Арктикуголь» по месторождению «Пирамида». При бурении в углеразведочных целях в 1990-1993 гг. скважин на северном и восточном берегах бухты Петунья на глубинах от 200 до 750 м были вскрыты нефтеи газонасыщенные отложения.

На протяжении полувека советские (позже - российские) геологи проделали на архипелаге Шпицберген большую работу, которая завершилась открытием первых залежей нефти и газа. Российскими предприятиями, проводившими геолого-геофизические и буровые работы на архипелаге, в том числе ВНИИОкеангеология, ПМГРЭ и «Севморгео», накоплен большой объем информации, характеризующей различные аспекты перспектив нефтегазоносности архипелага. Ни одна из стран, осуществляющих здесь подобные исследования, включая Норвегию, не имеет столь разностороннего объема фактических данных.

В целом выполненные оценки ресурсов углеводородов в районе Биллефьорда, бухты Петуния и Эббадаллен по категориям $\mathrm{C}_{3}$ и Д составили 15,2 млн т нефтяного эквивалента (н.э.), в пределах Нордфьордской площади - 234 млн т.н.э., на Земле Бюнсова -65 млн т. Принимая во внимание слабую изученность перспективных на нефть комплексов, здесь вполне вероятны средние и мелкие промышленные месторождения. При высоких ценах на нефть и с учетом значительных суммарных ресурсов их разработка может оказаться рентабельной.

\section{Изучение угленосности на Шпицбергене}

Разработка угольных месторождений на архипелаге многие годы всеми участниками велась не столько по экономическим мотивам, сколько для обоснования наличия своих поселений на архипелаге. Так, норвежские власти уже к 1920 г. пришли 
к выводу, что добыча угля вряд ли будет прибыльной. В связи с этим возникла необходимость поддерживать внутренний спрос на шпицбергенский уголь со стороны государства, чтобы сохранить поселение.

СССР, в свою очередь, подчеркивал, что поставки угля со Шпицбергена имеют большое значение для промышленности Мурманской и Архангельской областей, кроме того, до войны шпицбергенский уголь был необходим для стратегически важной Мурманской железной дороги. Северный флот СССР появился после 1945 г. и не зависел от поставок угля с архипелага.

В 1976 г. в НИИГА была начата разработка темы «Угленосные отложения архипелага Свальбард», нацеленная на обобщение и систематизацию основных материалов по угленосным отложениям архипелага, районирование угленосной территории, выделение месторождений и участков с их геологической характеристикой, соответствующей стадии изученности, а также оценку прогнозных запасов угля, определение перспектив освоения и развития. В процессе полевых работ 1977-1980 гг. изучался керн вновь пробуренных скважин на месторождениях Баренцбургском и «Пирамида», кроме того, геологи посетили западную часть Земли Натхорста, о. Медвежий, участки Грумант, Струве, Хёджхог.

В результате были обобщены и систематизированы все имевшиеся на тот период материалы по ископаемым углям Шпицбергена. По новейшим данным составлено геологическое описание архипелага, приведены характеристика его угленосности, качества и метаморфизма углей, оценка угольных ресурсов. Впервые выполнено районирование угленосности, выделены угленосные площади, месторождения и участки с их геологическим описанием. В общей сложности на архипелаге выделено пять геолого-экономических районов с 34 угольными объектами (угольные площади, месторождения, участки). Количество рабочих пластов в угленосных толщах обычно не превышает $1-4$, мощность их изменяется от кондиционной $(0,6$ м) до $1-3$ м, иногда до 7 м.

Ресурсы углей архипелага Свальбард оценены до глубины 600-1200 м ниже уровня моря в количестве 836 млн т, из которых 263 млн т считаются штольневыми, а остальные 573 млн т шахтными. Большая часть запасов (618 млн т) представлена газовыми углями, на долю газовых жирных приходится примерно
186 млн т, на долю коксовых - всего около 30 млн т. Запасы по категориям $\mathrm{A}+\mathrm{B}+\mathrm{C}_{1}$, выделенные только на российских разведанных и освоенных промышленностью участках, составляют всего 20 млн т. Все другие запасы углей классифицируются как прогнозные (категория $\mathrm{C}_{3}$ ).

Объемы добычи угля на Шпицбергене в разные годы варьировали в зависимости от мировых цен на него и количества средств, выделяемых Норвегией и Россией (СССР) в качестве субсидий на компенсацию затрат при разработке угольных шахт. На российских шахтах добывалось от 300 до 600 тыс. т в год, на норвежских - от 300 тыс. т до 2 млн т в год [Геолого-геофизические.., 2015].

В настоящее время разработка углей производится на одном месторождении «Баренцбург» трестом «Арктикуголь» (общая добыча около 120 тыс. т) и месторождении «Лонгйир» (шахта № 7) норвежской угольной компанией «Стуре Ношке», которая ежегодно добывает примерно столько же угля для энергетического обеспечения поселка Лонгйир. Падение объемов добычи угля у норвежской и российской компаний обусловлено снижением мировых цен на него. Ранее добыча угля производилась на месторождениях «Грумант», «Пирамида», «Свеагрува» и «Ню-Олесунн», кратковременно угли разрабатывались также на месторождении «Адвент» и участке тундры Богемана.

Тресту «Арктикуголь» принадлежали на архипелаге ряд угольных участков. Это участки рудников «Баренцбург» и «Пирамида», тундры Эрдмана, тундры Богемана, «Грумант», участки в среднем течении р. Рейн, в районе бухт Колд и в северо-восточной части Земли Геера, а также в районе «Пирамиды» (Цитадель и Триунген). Из них, по мнению российских специалистов, заслуживают внимания и дальнейшего изучения участки: Грумант, площадь среднего течения р. Рейн и у бухты Колд, северо-восток Земли Геера. Из свободных, еще никем не занятых участков, тресту «Арктикуголь» рекомендуется приобретение угленосной площади Сассен (прогнозные запасы - 23 млн т), центральной части о. Медвежий (прогнозные запасы коксовых углей $-10-15$ млн т) и участка Лундстрём (10 млн т)

Для приобретения прав у иностранных угольных компаний, кроме угленосных площадей, примыкающих к нашим участкам, 
могут быть рекомендованы месторождения «Ню Олесунн» с очень ценными для химической промышленности углями с высоким выходом смолы, а также участки месторождений «Лонгйир», «Свеагрува», «Адвент» и «Ворди», «Земля Бюнсова». Эти выводы, полученные в итоге работ геологов НИИГА - ВНИИОкеангеология, особенно актуальны в наши дни, когда запасы действующей шахты «Баренцбург» почти исчерпаны. Однако в последние годы трестом «Арктикуголь» не только не приобретались новые участки, но были утрачены права и на ряд резервных площадей, закрепленных за ним в советский период.

Нынешнее состояние российского статуса на Шпицбергене в значительной мере понизилось из-за практически полного исчерпания запасов каменного угля на рудниках «Пирамида» (законсервирован) и «Баренцбург».

Рудник «Баренцбург» остался последним из трех, ранее эксплуатировавшихся трестом «Арктикуголь», и сейчас работает лишь на обеспечение внутренних потребностей одноименного поселения. Норвежская сторона в октябре 2017 г. заявила, что оставляет только одну угольную шахту из трех имеющихся на Шпицбергене. Норвежские власти рассчитывают на то, что в среднесрочной перспективе им удастся найти способ обеспечить рентабельность двух шахт, а также на то, что цены на уголь вырастут. Для поддержания угольной промышленности Шпицбергена компании «Стуре Ношке» из бюджета королевства должно быть выделено 110 млн норвежских крон².

\section{Другие виды полезных ископаемых}

Залежи фосфоритов соответствуют промышленным месторождениям и в будущем вполне могут стать объектом долговременной и рентабельной разработки, так как потребность в фосфорных удобрениях на мировом рынке неуклонно растет.

Важным результатом выполненных работ является открытие и выделение Центрально-Шпицбергенской медно-полиметаллической зоны, ее ранговое структурирование с выделением ряда рудных полей [Евдокимов, 1990]. В целом они соответствуют крупному месторождению. Ресурсы меди на рудном поле Вонбреен составляют около 4,5 млрд долл., серебра - 825 млн долл.

${ }^{2}$ URL: https://regnum.ru/news/economy/2131064.html (дата обращения: 21.02.2018).
[Евдокимов, 1990; Твердые полезные.., 2010; Сироткин и др., 2007].

Новым видом сырья для архипелага стал флюорит, его проявления ассоциируют с полиметаллами. Комплексное освоение руд полиметаллов, киновари, благородных металлов, флюорита, барита будет способствовать повышению рентабельности их разработки.

В результате совместных исследований ФГУНПП ПМГРЭ и ВНИИОкеангеология были обнаружены проявления кимберлитовых тел, что указывает на возможность обнаружения продуктивных кимберлитов. С этой целью необходимо продолжить работы по поискам и опробованию на алмазы известных и вновь открываемых объектов.

\section{Научная деятельность на архипелаге должна стать основой для дальнейшего развития}

Научная деятельность - веское основание для мотивации присутствия России на архипелаге.

Еще до начала Первой мировой войны Шпицберген ежегодно посещали научные экспедиции, а в межвоенный период, несмотря на тяжелую экономическую ситуацию, здесь работали исследовательские группы. После Второй мировой войны научная деятельность все больше набирала обороты, за последние несколько десятилетий исследования как на российской, так и норвежской частях архипелага переживают настоящий бум.

Научные исследования были каналом сотрудничества и обмена информацией между Норвегией и СССР, особенно в период холодной войны, когда контакты на официальном уровне были ограничены, способствуя предотвращению международных конфликтов.

В 2014 г. постановлением Правительства РФ был организован научный комплексный консорциум в форме Российского научного центра на Шпицбергене по изучению экологических проблем Севера, климатических особенностей региона, биологического разнообразия, влияния Арктики на человека, геологических особенностей архипелага и прилегающих акваторий. При этом была начата деятельность Российской арктической экспедиции под кураторством Арктического и антарктического гидрометеорологического института в Санкт-Петербурге. 
В последние годы на архипелаге становится все больше экологически ориентированных исследований. Это отражает общий рост интереса в мире к вопросам экологии. Важнейшими и практически значимыми направлениями работы экспедиции являются:

- мониторинг окружающей среды;

- организация студенческих практик с выездом на полевые работы на Шпицберген;

- организация маршрутов и групп научного туризма;

- обеспечение снаряжением, транспортом и жильем участников экспедиций;

- подготовка к публикациям и публикация результатов научных исследований.

Картографические материалы, созданные российскими учеными по различным частям архипелага, представляют большой интерес для международной научной общественности. Карты польских и норвежских исследователей регулярно печатаются и продаются в магазинах норвежского поселка Лонгйир, в то время как отечественные данные хранятся в архивных фондах, и о них никто, кроме авторов и узкого круга российских специалистов, не знает. Публикация отечественных картографических материалов на русском и английском языках позволила бы пропагандировать успехи научных исследований России и частично компенсировать затраты на научные изыскания.

С 2016 г. расширено международное и научно-образовательное направление деятельности российских организаций. Общий объем финансирования деятельности Российского научного центра в 2016 г. составил около 120 млн руб. Кроме того, центру были предоставлены научные гранты в объеме свыше 30 млн руб. В 2016 г. был значительно расширен спектр работ на архипелаге. В частности, заложен криосферный полигон в районе поселка Баренцбург по стандарту CALM, эпизодические наблюдения за состоянием льда на леднике Норденшельда заменены длительными комплексными, впервые произведены длительные наблюдения за гидрологическим режимом залива Грен-фьорд и рек его бассейна, охватывающие все стадии гидрологического цикла ${ }^{3}$

URL: https://meteoinfo.ru/news/1-2009-10-01-09-03-06/13485-14112016- (дата обращения: 25.02 .2018$)$
Для совершенствования организации геологоразведочных работ на Шпицбергене предлагается усилить ее научную составляющую: формировать группы специалистов с целью решения локальных задач в области прогнозирования месторождений полезных ископаемых, выполнения полевых работ и сбора каменного материала, составления геологических карт, квалифицированного анализа собранного материала в лабораториях и подготовки к публикации полученных данных. Успех экспедиций напрямую зависит от наличия водного и воздушного транспорта. Необходимо на полевой сезон на Шпицбергене использовать мобильное экспедиционное судно, подобное норвежскому катеру, совершающему регулярные рейсы для туристов по маршруту Баренцбург - Лонгйир - Пирамида.

Россия на Шпицбергене, кроме действующего угледобывающего треста «Арктикуголь», который сохраняет инфраструктуру российских поселков и добывает уголь, имеет крупный задел в области геологического изучения архипелага. Требуется эффективно задействовать накопленные за многие десятилетия материалы геолого-поисковых работ, а также продолжить начатые изыскания на современном научном и организационном уровне.

После 1990 г. экономика архипелага демонстрирует черты постиндустриальной эпохи, которая выражается, прежде всего, в росте «индустрии знаний». В качестве новых видов деятельности на архипелаге перспективны туризм, образовательные услуги и международные научные исследования. Примечательно, что Норвегия, которая во все большей степени пытается примерять на себя роль «хозяина» архипелага, обосновывает это именно профессиональным лидерством в новых областях. В частности, Норвегия уже реализовала (или имеет планы по реализации) на Шпицбергене следующие крупные международные проекты, относящиеся к постиндустриальной эпохе.

1. В 1995 г. картографическое ведомство этой страны открыло на архипелаге передовую геодезическую станцию на основе проекта Европейской организации космических исследований. Диспетчерскую построили на фундаменте одной из телеметрических антенн. Партнер проекта - NASA - разместило на станции оборудование, способное точно регистрировать географические и астрономические данные. 
2. В 2008 г. под эгидой ООН было построено уникальное семенохранилище (для хранения 4,5 млн образцов семян), и в настоящее время коллекция уже составляет 770 тыс. образцов. В случае глобальной или региональной катастрофы запасы семян позволят восстановить сельскохозяйственное производство. Семенной материал можно также использовать для выведения новых сортов растений 4 .

3. Норвежская компания Kolos планирует строительство гигантского дата-центра за Полярным кругом на территории континентальной Норвегии. Низкая среднегодовая температура, дешевые и экологичные источники электроэнергии (вода и ветер), подходящие для нужд центра горные выработки, оставшиеся здесь с прежних времен - всё это привлекло внимание инвесторов. Современные дата-центры потребляют много энергии, хранят массу информации, производят сложные вычисления и требуют очень мощной системы охлаждения поддержки стабильной работы ${ }^{5}$. Шпицберген является идеальным местом для строительства таких объектов в будущем и международного сотрудничества в этом направлении.

Таким образом, России, если она действительно закрепилась на Шпицбергене «всерьез и надолго», необходимо активнее подкреплять свои усилия и намерения более широкой научной и инновационной деятельностью в сотрудничестве с другими странами, а не ориентироваться исключительно на безусловное военное и геополитическое превосходство.

\section{Россия и Норвегия на Шпицбергене -} соседи или соперники?

В экономическом и политическом отношениях на протяжении большей части XX в. архипелаг имел стратегическое значение как для Норвегии, так и для СССР, хотя основания для этого интереса менялись.

Норвежский исследователь Тур Б. Арлов [Арлов, 2016] отмечает, что «...Норвегия придавала Шпицбергену большое значение как в двусторонних отношениях с СССР, так и в международной

${ }^{4}$ URL: https://scandinews.fi/society/story/483-na-vsyakij-yadernyij-sluchaj.-vsemirnoesemenoxranilishhe-na-shpiczbergene (дата обращения: 21.02.2018).

URL: https://project-splash.com/posts/data-centr-zanbsppolyarnym-krugom/dj7c15773a6 (дата обращения: 21.02.2018). политике в целом. Такая политическая линия исходила из предположения, что русские имели аналогичные интересы... Мы не знаем точно, каковы были мотивы Советского Союза и что лежало в основе принятия тех или иных политических решений. И политикам, и исследователям приходилось только догадываться о реальных интересах русских на Шпицбергене. Анализ открытых советских архивов показывает, что архипелаг на протяжении долгого времени играл малозначимую роль в советской внешней политике, по крайней мере, менее значимую, чем полагали в Норвегии... ».

Хотя стратегическое значение Шпицбергена не стоит преувеличивать, с сожалением приходится констатировать, что геополитическая обстановка вокруг архипелага почти не изменилась со времен окончания холодной войны. Так, постоянным раздражителем для Норвегии остается значительная военная инфраструктура России на Кольском полуострове, что, по мнению Норвегии, кроме чисто геополитических причин, представляет угрозу для окружающей среды. Северный флот России в последние годы наращивает свою активность в регионе, что вызывает ответную реакцию Норвегии.

Однако территория Шпицбергена составляет примерно пятую часть от территории континентальной Норвегии, и эта страна, развивая свое присутствие на архипелаге, в значительной степени руководствуется политическими, а не экономическими мотивами. Для Норвегии Шпицберген (особенно на заре его промышленного освоения) являлся важной составляющей для самоутверждения этого государства - страна развивала деятельность на архипелаге даже после того, как стало очевидно, что добыча угля не может быть коммерчески привлекательной.

В этих условиях Норвегия совершает настойчивые попытки по «укреплению суверенитета» на Шпицбергене, что зачастую противоречит прежним договоренностям, закрепляющим статус архипелага как открытой территории. Так, в последние 15 лет наблюдается устойчивая тенденция по ограничению деятельности российских научных экспедиций на Шпицбергене со стороны норвежской администрации, несмотря на то, что все страны, подписавшие Парижский договор о Шпицбергене, располагают равными правами в хозяйственной и научной деятельности. В частности, все больше территорий архипелага объявляются 
заповедными или национальными парками с ограничениями по времени и условиям научной работы на их площадях.

Практически невозможно использовать отечественный вертолет для заброски научных отрядов в районы, удаленные от населенных пунктов, - для этого требуются лицензия и специальное предварительное согласование. Все научные отряды должны регистрироваться в Норвежском научном центре с указанием сроков, состава, целей исследований и ожидаемых результатов. При этом, в отличие от российского научного центра, норвежский приглашает наших ученых участвовать в своих программах, распределяет специальные гранты и собирает полученную научную информацию.

Особенно показательны действия администрации на территориях, где российские геологи находили интересные в промышленном отношении геологические объекты. Например, обнаружение золота на участке в береговых породах Сент-Джонсфьорда в последующем было реализовано норвежской компанией Ношк-Гидро, заявлено и подтверждено пробами с высокими содержаниями металла на глубине до 500 м.

Находки алмазоперспективных пород в Экман-фьорде и на полуострове Петерман оказались в пределах вновь образованного заповедника, а нефтеперспективные участки на Земле Бюнсова после обнародования российских геологических работ также стали частью национального парка, в пределах которого, с точки зрения Норвегии, нельзя вести геологоразведочные и добычные работы.

Россия регулярно поднимает вопрос о том, что Норвегия подобными действиями нарушает положения Парижского договора. По словам главы МИД С. Лаврова, в 2017 г. дипломаты несколько раз обращались к норвежским соседям с официальными нотами, в том числе дважды в 2016 г., с просьбой ответить на озабоченности, объяснить пути их преодоления. До сих пор ответов на эти ноты не поступило 6 . Такая же проблема обозначена в 2017 г. в докладе Министерства обороны России «О комплексной оценке состояния национальной безопасности РФ в области морской деятельности в 2016 г.». В частности, одной из угроз, по мнению авторов документа, является то, что Норвегия стремится к установлению «абсолютной национальной юрисдикции над архипелагом Шпицберген и прилежащей 200-милльной акваторией» ${ }^{7}$.

Не сняты разногласия и по принадлежности континентального шельфа Шпицбергена. Россия придерживается позиции, что архипелаг имеет свой шельф, который должен регулироваться Договором о Шпицбергене. Норвежская точка зрения состоит в том, что шельф архипелага - это часть континентального шельфа материковой Норвегии, а значит, его принадлежность определяется Конвенцией о континентальном шельфе 1958 г., и на шельфе Шпицбергена должен действовать национальный норвежский режим с его крайне высокими налогами.

\section{Российское присутствие на Шпицбергене - куда двигаться?}

За последние десятилетия история развития Шпицбергена пережила несколько взлетов и падений. При этом до 1980-х гг. российская часть архипелага развивалась в целом синхронно с норвежской.

В первые десятилетия XX в. на Шпицбергене происходили серьезные перемены. В экономическом плане архипелаг привлекал индустриальные страны залежами полезных ископаемых (прежде всего, угля). Их добыча создала предпосылки для круглогодичной деятельности в гораздо большем объеме, чем прежде: требовалось создать обширную инфраструктуру, чтобы в зимнее время не зависеть от материка. В начале 1960-х гг. угледобывающая отрасль пережила серьезный кризис, и обсуждался вопрос о полном ее прекращении на архипелаге. Высказывались предположения, что на смену шахтам придут нефтедобыча и рыболовство.

Норвежское правительство исходило из того, что угледобыча является основной возможностью сохранить норвежские поселения на архипелаге. В середине 1970-х гг. угольные предприятия Норвегии были национализированы. Одновременно были вложены значительные средства в расширение норвежского присутствия в регионе и «нормализацию» местного общества, т.е. приведение уклада и уровня жизни к уровню континентальной Норвегии. Были сделаны первые шаги по диверсификации экономики, а жителям архипелага предоставлены налоговые льготы. 
В начале 1990-х гг. в поселениях на Шпицбергене, как российских, так и норвежских царила неопределенность. Обеспокоенность в связи с уменьшением угольных запасов и плохой рыночной конъюнктурой объединила угольные компании обеих стран. В российской части Шпицбергена проблемы были связаны с распадом СССР. В этот период были сделаны первые попытки (впрочем, не очень удачные) диверсификации экономики российской части архипелага. Например, рассматривалась возможность строительства завода минеральной воды, источник которой был открыт недалеко от Баренцбурга. На основе этого источника предлагалось построить бальнеологический центр. Также обсуждался проект добычи водорослей для использования в качестве биологически активных добавок в птицеводстве.

Между тем Норвегия провела реструктуризацию компании «Стуре Ношке» - главного получателя государственных субсидий. Были сделаны попытки активизировать развитие местной промышленности, проведена частичная приватизация и демонополизация государственных предприятий на архипелаге. В 1993 г. норвежский шахтерский поселок Лонгйир был продан национальному правительству, которое сконцентрировалось на развитии университетского центра и туризма.

В российской части архипелага эти процессы были более инерционными. Россия во многом сохранила советский подход к развитию Шпицбергена, при котором изолированные от «большой земли» территории функционировали в рамках модели моногородов («город-предприятие»).

Несмотря на открытость архипелага, российский бизнес на Шпицбергене практически отсутствует. При этом государственная собственность используется крайне неэффективно и требует затрат как на поддержание, так и для сохранения юрисдикции (норвежский закон устанавливает максимальный срок заброшенности объектов). Фактически пока все предложения по развитию российской части архипелага в той или иной форме сводятся к необходимости роста постоянных дотаций; их детальная проработка отсутствует, а объем предполагаемых инвестиций неясен. Россия по-прежнему делает основную ставку на угледобычу на архипелаге, другие стратегии развития, помимо добычи полезных ископаемых, отсутствуют. Кроме того, переносу деятельности российских компаний на новую территорию препятствует экологическая политика Норвегии.

В 1998 г. шахта в поселке Пирамида была законсервирована, а население эвакуировано. Были опасения, что российское присутствие на Шпицбергене подходит к концу. Тем более что этому предшествовал ряд происшествий (катастрофа вертолета в 1996 г. и взрыв на шахте в Баренцбурге в 1997 г.). Однако этого не произошло, и даже началось строительство новой шахты на месте Грумантского месторождения.

Сейчас обе страны развивают туристический потенциал архипелага, правда, у Норвегии это выходит успешнее. Норвежский поселок Лонгйир привлекателен для тех, кто хочет увидеть Арктику, но боится отказаться от условий цивилизации. Российские поселки Грумант, Пирамида и Баренцбург тоже стали туристическими местами, в особенности для любителей снегоходных туров ${ }^{8}$.

Наука и туризм переживали подъем как на рубеже XIX$\mathrm{XX}$ вв., так и XX-XXI вв. Интернационализация - один из положительных векторов в истории Шпицбергена. В последнее десятилетие этот вектор только усилился, а значительный вклад в его укрепление внесли туризм, научные исследования и образование.

России следует воспользоваться этими открывающимися возможностями международного сотрудничества и сменить устаревший формат экономической деятельности в регионе. Хозяйственная деятельность на Шпицбергене (и в Арктике в целом) находится в процессе непрерывной трансформации. Формы и подходы, базирующиеся на жесткой субординации и экономическом диктате государственных компаний, постепенно уступают дорогу основанным на кооперации, партнерстве и взаимодействии. Это позволит не только снижать высокие природноклиматические и экономические риски, но также находить более приемлемые для территории и населения и решения.

По нашему мнению, динамика форм и подходов к ведению международной хозяйственной деятельности на Шпицбергене на протяжении столетия зависела от стадии развития архипелага. Можно выделить следующие основные этапы, характерные как для российской, так и для норвежской его частей:

${ }^{8}$ URL: https://regnum.ru/news/2336854.html 
1) индустриализация, обособление национальных зон (1900-1950 гг.);

2) активные научные исследования, упор на «политическую целесообразность» присутствия на архипелаге (1950-1990 гг.);

3) разгосударствление деятельности (1990-2000 г.);

4) переход на новый уровень научных исследований, «индустрия знаний», международное сотрудничество, туризм (после 2000 г.).

К сожалению, Россия только начинает реализацию тех шагов, и мер, которые Норвегия осуществила в 1990-е годы. Этот процесс осложняется непростой геополитической обстановкой в мире и активной позицией Норвегии, считающей себя единоличным «хозяином» архипелага. Во многом это стало следствием отсутствия у России четкой стратегии по развитию Шпицбергена в последние десятилетия. Решение находится в сфере усиления международного сотрудничества в науке, образовании, туризме в сочетании с развитием инновационной деятельности и привлечением частного бизнеса на архипелаг. России следует использовать свое преимущество - колоссальный опыт ведения геолого-поисковых работ на архипелаге, которые можно и нужно продолжить в рамках новой парадигмы развития, опирающейся на международное сотрудничество и открытость.

\section{Литература}

Арлов Т. Б. История архипелага Шпицберген. М.: Паулсен, 2016. 592 с.

Геолого-геофизические исследования Шпицбергенской геолого-поисковой партии на архипелаге Шпицберген (1962-2015). Библиографический справочник / Под ред. Сироткина А.Н. ФГУНПП «ПМГРЭ», г. Ломоносов, 2015, 160 с.

Евдокимов А.Н. Новое рудопроявление меди на Шпицбергене, ДАН СССР, 1990. T. 314. № 4. C. 915-918.

Наука на Шпицбергене: История российских исследований / Под ред. акад. РАН Калинникова В. Т. Спб: «ГАМАС», 2009, 408 с.

Сироткин А.Н., Хайлов В.В., Никитин Д.В. Минералогия и генезис рудопроявлений Центрально-Шпицбергенской полиметаллической зоны (о. Западный Шпицберген). ЗРМО. 2007. Ч. 136. № 5. С. 76-93.

Твёрдые полезные ископаемые архипелагов и островов арктической континентальной окраины Евразии / Отв. ред. В.И. Ушаков. Спб, ВНИИОкеангеология, 2010. 336 с.

\section{Summary}

Evdokimov A.N., St. Petersburg Mining University, St. Petersburg

Sirotkin A.N., Spitsbergen party of the Polar sea prospecting expedition, Lomonosov

Kryukov Ya.V., Institute of Economics and Industrial Engineering, SB RAS, Novosibirsk

Russia on Spitsbergen: History of Studying, a Problem of Development of a Subsoil and Prospect on the Future

The little-known Russian territories with the official status of "own lands" are located On Spitsbergen (Svalbard). Here are several coal-fields in which development are engaged the state trust "Arktikugol" on the field Barentsburg and Norwegian "Sturre Norske" near Longiyerbyuen. Russia has done all range of geological researches of the archipelago in Soviet period, paying the main attention to mapping and a research of reserves of minerals: coal, oil, phosphorites, polymetals, gold. However, the Norwegian administration of the archipelago in every possible way brakes a possibility of their further studying and development, putting forward ecological motives not of a possibility of conducting exploration works. While reserves of coal will be over the Russian presence on the archipelago can be developed in implementation of scientific programs conducted with the new Russian research center formed in Barentsburg in 2014.

Spitsbergen; Russian presence in the Arctic; geological research; economy of the northern territories; Norway; international cooperation in the Arctic

\section{References}

Kalinnikov V.T. ed. (2009). Nauka na Shpitsbergene: Istorija rossijskih issledovanij. Saint-Petersburg, GAMAS Publ. 408 p. (In Russ.)

Sirotkin A. N. ed. (2015). Geologo-geofizicheskie issledovanija Shpitsbergenskoj geologo-poiskovoj partii na arhipelage Shpitsbergen (1962-2015). Bibliograficheskij spravochnik. Lomonosov, FGUNPP PMGRE Publ. 160 p. (In Russ.)

Evdokimov A. N. (1990). Novoe rudoprojavlenie medi na Shpitsbergene. DAN USSR Publ., Vol.313. No. 4. Pp. 915-918. (In Russ.)

Ushakov V.I. ed. (2010). Tvjordye poleznye iskopaemye arhipelagov i ostrovov arkticheskoj kontinental'noj okrainy Evrazii. Saint-Petersburg, VNIIOkeangeologiya Publ. 336 p. (In Russ.)

Sirotkin A.N., Khailov V.V., Nikitin D.V. (2007). Mineralogija i genezis rudoprojavlenij Central'no-Shpitsbergenskoj polimetallicheskoj zony (o. Zapadnyj Shpitsbergen). Papers of the Russian Mineralogical Society. Vol.136. No. 5. Pp. 76-93. (In Russ.)

Arlov T. B. (2016). Istorija arhipelaga Shpitsbergen. Moscow, Paulsen Publ. 592 p. (In Russ.) 